\title{
Vegetable grafting - a tool to improve vegetable productivity
}

\section{Introduction}

Agricultural grafting was started practicing two thousand years back in Asia, and it was mention in China's history. This plant surgical technique is defined as the vegetative and asexual method of plant propagation and done by combining two separate plants i.e. upper part contain shoot system of high yielding commercial cultivar called as 'scion' and lower part known as 'rootstock' with desired root system characteristics into a single independent plant possessing interested trait. Since grafted plants have a long history of use in woody/fruit trees, but in present scenario, grafting is used in various herbaceous plants such as vegetables and flowers. Practicing of grafting in vegetable crops is an exclusive tool in East Asia to manage various vulnerable issues to the intensive vegetable production. In this regard, the first scientific report of vegetable grafting was published during late 1920 in Japan Journal of Horticulture. ${ }^{1}$ This study was designed to control soil borne disease especially fusarium and to improve crop productivity in watermelon (Citrullus lanatus) by grafting the seedlings onto squash rootstock (Cucurbita moschata). After this scientific documentation, grafting in vegetables particularly in cucurbits started scattering from Japan to other neighboring countries like Korea, China etc. and initiated to manage soil borne diseases especially Fusarium. ${ }^{2}$ Subsequently, the production of watermelon grafted seedlings at commercial level started in early 1930s in Japan. ${ }^{3}$

Presently, grafting becomes popular technology among the vegetable growers and scientist to develop resistance or improve tolerance against the broad spectrum of biotic and environmental stresses in the various vegetable crops specifically solanaceous and cucurbitaceous crops. Therefore, scientists working on grafting are primarily focusing to enhance yield without altering fruit quality; scion-rootstock compatibility/incompatibility; resistance towards soil borne diseases; to investigate communication between shoot and root system. ${ }^{4}$ Furthermore, the success of grafting hinges on compatibility of the shoot and root system of the grafted plants, and it is decided by connecting vascular systems of both the tissues. Generally, it is said that more taxonomical related plants are more compatible than distant taxonomically different. Large number of research groups in US, Asia, and European countries like Spain, Italy, and Turkey has been focusing to elucidate various mechanisms and alterations involved in scion and root system physiologically, biochemically, genetically and at molecular level since decade. So, grafting technique has many benefits for vegetable crop production and discussed as follow.

\section{To manage soil borne diseases}

Various vegetable crops are serious threaten by soil borne diseases. Since 1930s, grafting has been using to create resistance against the soil borne diseases in vegetable crops. It was found the best alternate after the phase out of Methyl Bromide Fumigation which was usually used to control soil-borne diseases. Thus, this technique is exclusively using to manage mainly fusarium, bacterial, and verticillium wilt in tomato and melons. Furthermore, this is one of the effective techniques to control root knot nematodes in solanaceous and cucurbitaceous crops by grafting susceptible commercial cultivars
Volume 4 Issue 4 - 2016

\author{
Hira Singh,' Mahmoud Soltan² \\ 'Department of Vegetable Science, Punjab Agricultural University, \\ India \\ ${ }^{2}$ Ohio State University, USA
}

Correspondence: Hira Singh, Department of Vegetable Science, Punjab Agricultural University, India, Email hira@pau.edu

Received: July 27, 2016 | Published: September 0I, 2016

onto resistant rootstocks. For this, various wild species has been exploiting for disease resistance. The soil borne diseases are likely to enhance further due to continuous cropping pattern and not complete soil sterilization, so this technique becomes critically significant for the fruit vegetables to grow repeatedly.

\section{Higher adaptability to environmental stresses}

Due to succulence of vegetable crops, these are highly susceptible to environmental changes. The change in temperature and erratic rainfall cause drought, flooding, and salinity which led to serious loss of vegetable crop production. It can be said that production of vegetable crops is challenging under changing climate. At commercial level, development of tolerant cultivars using breeding is limited due to genetically and physiologically complexity of the abiotic stresses. Moreover, except few, many vegetable crops do not have resistant crossing compatible wild resistant sources. In this situation, grafting a plant surgical technique has effectively been used to mitigate broad spectrum of various environmental pressures. Particularly, in tomato and melons, grafting of high yielding commercial sensitive cultivars onto rootstock having resistance and vigorous root system has showed great success for improving many environmental stresses. Thus, grafting in fruit bearing vegetable crops is attaining wide popularity at the global level.

\section{Enhancement of yield with better fruit quality}

From economic view, high yielding and better fruit quality is important for the fruit bearing vegetable crops. Nonetheless, due to various pest, diseases, and environmental pressures vegetable productivity has been influenced significantly. The grafted vegetable plants with resistance/tolerance of biotic and abiotic stressors has increased yield and quality in the plants, but this improvement depends on the genotype of scion and rootstock, their compatibility, and reciprocal effect on each other. Moreover, root system of rootstock plays a great role to effect epigeous part of grafted plants under rhizosphere stresses..$^{5}$ For instance, grafted mini-watermelon and cucumber plants possessed higher vitamin $\mathrm{C}$ contents in fruits than non-grafted plants. ${ }^{67}$ In domesticated tomato, variability for abiotic stresses especially salt tolerance is limited. But, wild species such as S. pimpinellifolium, S. peruvianum, S. cheesmaniae, S. habrochaites, 
S. chmielewskii and S. pennellii in the genus Solanum possessed sources of tolerance and the same have been exploited as rootstock to enhance productivity under wide environmental stress conditions, whereas, introgression with commercial tomato is difficult due to the problem of crossibility. ${ }^{8}$ Similarly, 27 per cent marketable yield per plant enhanced when cucumber seedlings grafted onto the pumpkin rootstock compare to the non-grafted plants of cucumber. ${ }^{9}$ In case of watermelon, the seedlings grafted onto the bottle gourd exhibited 27-106 per cent more yield over the control, but on the other hand, rootstock Cucurbita spp. reduced fruit yield by 127-240 per cent. ${ }^{10,11}$ Thus, grafted plants with weak rootstocks elicited lower yields than vigorous rootstock.

To sum up, grafting in vegetable crops especially in solanaceous and cucurbitaceous is highly useful to eliminate various challenging biotic and abiotic stressors globally. Proper selection of scion and rootstock is the key factor for higher fruit yield and quality. Under changing climate, this technique could play significant role to improve vegetable productivity. Thus, there is a need to identify more resistant sources by exploiting wild and elite germplasm.

\section{Acknowledgements}

None.

\section{Conflict of interest}

The author declares no conflict of interest.

\section{References}

1. Tateishi K. Grafting watermelon on squash. Japan Journal of Horticulture. 1927;39:5-8

2. Kubota C, McClure MA, Kokalis-Burelle N, et al. Vegetable grafting:History, use, and current technology status in North America. Hort Science. 2008:43(6):1664-1669.
3. Oda M. Grafting of vegetable crops. Scientific report of the graduate school of agriculture and biological sciences. Osaka Prefecture University (Japan). 2002;54:49-72.

4. Goldschmidt EE. Plant grafting:new mechanisms, evolutionary implications. Front Plant Sci. 2014;5:727.

5. Oztekin GB, Giuffrida F, Tuzel Y, et al. Is the vigour of grafted tomato plants related to root characteristics. Journal of Food Agriculture and Environment. 2009; 7:364-368.

6. Huang Y, Tang R, Cao Q, et al. Improving the fruit yield and quality of cucumber by grafting onto the salt tolerant rootstock under $\mathrm{NaCl}$ stress. Scientia Horticulturae. 2009;122(1):26-31.

7. Proietti S, Rouphael Y, Colla G, et al. Fruit quality of mini-watermelon as affected by grafting and irrigation regimes. Journal of Science, Food, and Agriculture. 2008;88:1107-1114.

8. Rao ES, Kadirvel P, Symonds RC, et al. Relationship between survival and yield related traits in Solanumpimpinellifolium under salt stress. Euphytica. 2003;190(2):215-228.

9. Seong KC, Moon JH, Lee SG, et al. Growth, lateral shoot development, and fruit yield of white-spined cucumber (Cucumis sativus cv. Baekseong-3) as affected by grafting methods. Journal-Korean Society for Horticultural Science. 2003;44(4):478-482.

10. Yetisir H, Sari N. Effect of different rootstock on plant growth, yield and quality of watermelon. Australian Journal of Experimental Agriculture. 2003;43(10):1269-1274

11. Yetisir H, Sari N, Yucel S. Rootstock resistance to Fusarium wilt and effect on watermelon fruit yield and quality. Phytoparasitica. 2003;31(2):163169 